\title{
Metagenomic Analysis of Some Potential Nitrogen-Fixing Bacteria in Arable Soils at Different Formation Processes
}

\author{
Agnieszka Wolińska ${ }^{1}$ - Agnieszka Kuźniar ${ }^{1}$ Urszula Zielenkiewicz ${ }^{2}$ - Artur Banach ${ }^{1}$. \\ ${\text { Dariusz } \text { Izak }^{2} \text { • Zofia Stępniewska }}^{1}$ - Mieczysław Blaszczyk ${ }^{3}$
}

Received: 20 June 2016 / Accepted: 14 August 2016/Published online: 31 August 2016

(C) The Author(s) 2016. This article is published with open access at Springerlink.com

\begin{abstract}
The main goal of the study was to determine the diversity of the potential nitrogen-fixing (PNF) bacteria inhabiting agricultural (A) soils versus wastelands serving as controls $(\mathrm{C})$. The soils were classified into three groups based on the formation process: autogenic soils (Albic Luvisols, Brunic Arenosols, Haplic Phaeozem) formed on loess material, hydrogenic soils (Mollic Gleysols, Eutric Fluvisol, Eutric Histosol) formed under the effect of stagnant water and lithogenic soils (Rendzina Leptosols) formed on limestone. In order to determine the preferable conditions for PNF bacteria, the relationships between the soil chemical features and bacterial operational taxonomic units (OTUs) were tested. Additionally, the nitrogen content and fertilisation requirement of the lithogenic (LG), autogenic (AG) and hydrogenic (HG) soils were discussed. The composition of the bacterial communities was analysed with the next-generation sequencing (NGS) by the Ion Torrent ${ }^{\mathrm{TM}}$ technology. The sequences were clustered into OTU based on a $99 \%$ similarity threshold. The arable soils tested were distinctly dominated by $\beta$ Proteobacteria representatives of PNF bacteria belonging to
\end{abstract}

Electronic supplementary material The online version of this article (doi:10.1007/s00248-016-0837-2) contains supplementary material, which is available to authorized users.

Agnieszka Wolińska

awolin@kul.pl

1 Department of Biochemistry and Environmental Chemistry, Institute of Biotechnology, The John Paul II Catholic University of Lublin, 1 I Konstantynów Str, 20-708 Lublin, Poland

2 Department of Microbial Biochemistry, Institute of Biochemistry and Biophysics PAS, 5a Pawińskiego Str, 02-206 Warsaw, Poland

3 Department of Microbial Biology, Warsaw University of Life Sciences, Nowoursynowska 159 Str, 02-776 Warsaw, Poland the genus Burkholderia. Bacteria from the $\alpha$-Proteobacteria class and Devosia genus were subdominants. A free-living Cyanobacteria population dominated in A rather than in $\mathrm{C}$ soils. We have found that both soil agricultural management and soil formation processes are the most conducive factors for PNF bacteria, as a majority of these microorganisms inhabit the AG group of soils, whilst the LG soils with the lowest abundance of PNF bacteria revealed the need for additional mineral fertilisation. Our studies have also indicated that there are close relationships between soil classification with respect to soil formation processes and PNF bacteria preference for occupation of soil niches.

Keywords Soil metagenomes $\cdot$ Next-generation sequencing · Nitrogen-fixing bacteria $\cdot$ Arable soils $\cdot$ Wastelands

\section{Introduction}

Nitrogen $(\mathrm{N})$ is an essential element for microbial and plant life $[1,2]$. Mineral $\mathrm{N}$ usually comes from three main sources: (a) atmospheric discharges, (b) the biological process of binding and (c) chemical synthesis. All bacteria that possess the capability of molecular $\mathrm{N}_{2}$ binding are diazotrophic prokaryotes belonging to two domains: Bacteria and Archaea. Biological $\mathrm{N}_{2}$ fixation is a process of conversion of elemental-unavailable $\mathrm{N}_{2}$ into ammonia $\left(\mathrm{NH}_{4}-\mathrm{N}\right)$ available to bacteria and plants [2]. In the elemental form, $\mathrm{N}_{2}$ can be used only by specialised microorganisms possessing an enzymatic nitrogenase system [3, 4]. A separate group of $\mathrm{N}$-fixing autotrophic bacteria are Cyanobacteria, constituting large nitrogen biomass in soils and being responsible for soil fertility [5]. Most soils (especially paddy soils) have a natural population of Cyanobacteria, which provides a no-cost potential source of $\mathrm{N}$ [6]. The function and diversity of 
Cyanobacteria are well recognised in desert soils [7], saline soils [8], biological soil crust [9] and rice paddy soils [6]. However, knowledge concerning their abundance in agricultural soils [10] and wastelands still remains limited.

The quantity of biologically fixed $\mathrm{N}_{2}$ is estimated at c.a. $2 \times 10^{13} \mathrm{~g} \mathrm{~N} /$ year [11]. Two modes of molecular $\mathrm{N}_{2}$ binding have been identified [12]: (a) symbiotic (Rhizobia, Frankia), usually amounting to c.a. $150-300 \mathrm{~kg} \mathrm{~N} / \mathrm{ha}$, and (b) nonsymbiotic (bacteria, endophytes, lichens, Cyanobacteria) ranging from 1 to $20 \mathrm{~kg} \mathrm{~N} / \mathrm{ha}$. Due to the absence of symbiotic bacteria, non-symbiotic $\mathrm{N}$ fixation is dominant in many ecosystems, i.e. in green areas of temperate zones, tropical evergreen forests, or deserts $[12,13]$. The global rate of $\mathrm{N}$ fixation (symbiotic + non-symbiotic) in natural ecosystems may provide $100 \times 10^{12} \mathrm{~g} \mathrm{~N} /$ year, which constitutes c.a. $10 \%$ of the annual plant demand. The average content of mineral nitrogen in the Polish soils is in the range of 76-90 kg N/ha in spring and $89-97 \mathrm{~kg} \mathrm{~N} / \mathrm{ha}$ in autumn [14, 15]. Dresler et al. [16] found that application of $N$-fertiliser above $121 \mathrm{~kg} \mathrm{~N} / \mathrm{ha}$ resulted in a significant increase in the $\mathrm{NO}_{3}-\mathrm{N}$ content in the surface soil layer. According to the Polish Statistical Office report [17], the use of mineral fertilisers in Lubelskie voivodeship amounted to $141.7 \mathrm{~kg} / \mathrm{ha}$, with nitrogen, phosphorus and potassium fertilisers accounting for 50, 20 and $38 \%$, respectively.

There is a relatively long list of symbiotic nitrogen-fixing bacteria. The most common symbiotic $\mathrm{N}_{2}$-binding bacteria present in the nodules are able to colonise the rhizosphere and infect legumes. They are classified as slow-growing Bradyrhizobium and fast-growing Rhizobium [2, 18]. In recent years, a number of the following $\mathrm{N}$-fixing bacteria capable of forming nodules have been isolated and classified into $\alpha$ - and $\beta$-Proteobacteria: Methylobacterium nodulans [3, 19], Blastobacter denitrificans [20], Devosia neptuniae, Devosia riboflavina and Devosia natans [19,20], Ochrobactrum lupini [21], Agrobacterium spp. [19], Azospirillum spp. [22], Herbaspirillum lustianum [23], Cupriavidus taiwanensis-recently known as Ralstonia taiwanensis [19], Burkholderia tuberum, Burkholderia phymatum and Burkholderia cepacia $[3,22,24]$, several strains of $\gamma$-Proteobacteria [25] and $\delta$ Proteobacteria [3].

The best-known and well-recognised processes of $\mathrm{N}_{2}$ fixation have been described for Rhizobia and legumes, i.e. peas, cow peas, beans and soybeans $[2,26]$. The root nodules of Rhizobia could reduce even c.a. 20 million tons of atmospheric $\mathrm{N}_{2}$ into $\mathrm{NH}_{4}-\mathrm{N}$, amounting to c.a. $65 \%$ of $\mathrm{N}$ utilised in agriculture [2, 26]. However, little is known about other nonsymbiotic soil bacteria inhabiting arable soils and having potential for biological $\mathrm{N}_{2}$ fixation. Therefore, we have tried to provide new knowledge about the biodiversity of potential nitrogen-fixing (PNF) bacteria in arable soils of different genetic origins. For this purpose, next-generation sequencing (NGS) technique was applied whereby it became possible to omit the inefficient laboratory culture step and acquire knowledge about the enormous microbial groups termed as viable but not cultivable (VBNC). Till now, metagenomic tools with respect to PNF bacteria were applied into the following samples: temperate, subtropical and tropical soils from India [27], Arabian sea oxygen zone [28], Dexing copper mine in China [29] and the experimental station of Embrapa Soja in Brazil [30]. In that context, our study is the first one where PNF bacteria were identified in arable and wasteland sites by NGS Ion Torrent ${ }^{\mathrm{TM}}$ technology.

The aim of the study was to recognise the diversity of the PNF soil bacteria and Cyanobacteria population living in seven types of arable soils (Albic Luvisols, Brunic Arenosols, Haplic Phaeozem, Mollic Gleysols, Eutric Fluvisol, Eutric Histosol, Rendzina Leptosols) versus non-cultivated soils (wastelands) classified into three groups according to the soil formation processes: autogenic (AG), hydrogenic (HG) and lithogenic (LG) soils. Also, correlations between the numbers of operational taxonomic units (OTUs) assigned to the potential $\mathrm{N}$-fixing bacteria and soil chemical variables were assessed. Furthermore, we presented the novelty of ecological studies by indication of relationships between soil science classification with respect to soil formation processes and the number of PNF bacterial OTU number in the three groups of soils.

\section{Methods}

\section{Experimental Sites}

The study site was located in the south-eastern part of Poland in Lubelskie voivodeship $\left(51^{\circ} 13^{\prime} \mathrm{N}, 22^{\circ} 54^{\prime} \mathrm{E}\right)$, as presented in Fig. 1. The limitation of the study site to one region was prompted by the fact that the Lubelskie voivodeship is characterised by a great diversity of soil types (all basic and Polish dominant soil units are represented here) and is one of the largest and most important agricultural areas in Poland. Farmlands occupy a total of $68 \%$ of Lubelskie voivodeship area, including arable lands up to $78.4 \%$, meadows and pastures $19.6 \%$ and orchards $2 \%$. Thirty-one soil units were studied; they were represented by the following soil types (FAO): Albic Luvisol (three samples, numbered 1-3), Brunic Arenosol (six samples, numbered 4 9), Haplic Phaezoem (one sample, numbered 10), Mollic Gleysol (two samples, numbered 11-12), Eutric Fluvisol (one sample, numbered 13), Eutric Histosol (one sample, numbered 14) and Rendzina Leptosol (two samples, numbered 15-16) of agricultural (coded A) and wastelandscontrols (coded C) were studied (Table 1).

Additionally, taking into account the soil's origin, the investigated material were classified into the three basic groups: autogenic —-formed from loess material, represented 
Fig. 1 Location of the study site in Lubelskie voivodeship within Poland (according to https://en. wikipedia.org/wiki/Lublin Voivodeship) with the scheme of soil sampling (according to $\mathrm{PN}$ R-04031:1997) from 16 locations of the Bank of Soil Samples

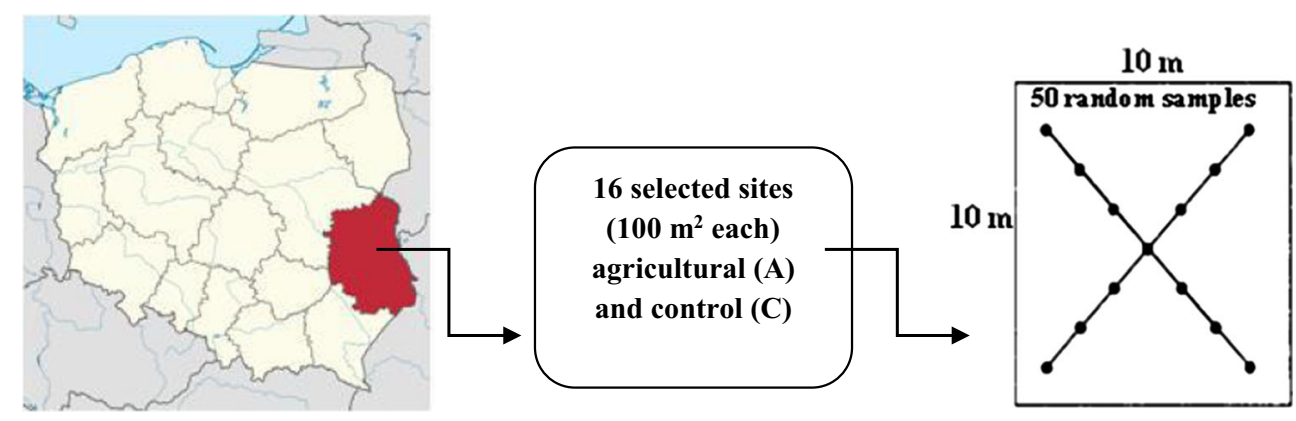

by Albic Luvisols (AL), Brunic Arenosols (BA) and Haplic Phaeozem (HP), hydrogenic - formed under the influence of stagnant water, represented by Mollic Gleysols (MG), Eutric Fluvisol (EF) and Eutric Histosol (EH) and lithogenicformed from limestone, represented by Rendzina Leptosols (RL). BA and AL cover c.a. $82 \%$ of Poland, hence the highest representativeness of these soil types in our soil collection ( 9 units of the 16 investigated ones). Soil material and sampling points were carefully selected on the basis of earlier work performed for typological soil recognition in 1991 within the framework of creation of the Bank of Soil Samples (BSS) creation by researchers from the Institute of Agrophysics, Polish Academy of Science in Lublin and the Institute of Land Reclamation and Grassland Farming in Falenty [31]. As an effect of this collaboration, a database for Polish mineral arable soils was created [32]. Given the precise description of the sampling points in the BSS database (name of place and geographic coordinates), there is a possibility of precise returning to the sampling sites [31].
Squares at $10 \times 10 \mathrm{~m}$ were chosen from each of the 16 sampling points catalogued in BSS database of Lubelskie voivodeship (Fig. 1). Within each square, approximately 50 random soil samples (c.a. $2 \mathrm{~kg}$ ) were taken from the surface layer $(0-20 \mathrm{~cm})$, strictly according to the sampling rules described in the Polish Norm [33]. Wasteland sites, belonging to the same soil type as agricultural lands and located in the nearest neighbourhood to arable soils served as controls. Random samples were combined into one sample in order to obtain the most representative soil material for each investigated site. In this manner, 16 samples were obtained for the agricultural (A) soils and 15 for the controls (C). Due to the close neighbourhood, the same soil, and crop type, soils (BA) numbered 5 and 6 have one control.

\section{Soil Characteristics}

The agricultural and control soils were sampled during the early spring season before plant vegetation and fertilisation (April 2014). An air temperature during sampling amounted
Table 1 Description of agricultural soils (Lubelskie voivodeship)

\begin{tabular}{lclll}
\hline Soil no. & $\begin{array}{l}\text { Soil group } \\
\text { (field code) }\end{array}$ & $\begin{array}{l}\text { Soil type } \\
\text { (FAO) }\end{array}$ & Geographic coordinates & Crop \\
\hline 1 & Autogenic & Albic Luvisol & $22^{\circ} 10^{\prime} 17.7^{\prime \prime}, 51^{\circ} 26^{\prime} 24.6^{\prime \prime}$ & Oat \\
2 & $(1-10)$ & Albic Luvisol & $22^{\circ} 27^{\prime} 10.3^{\prime \prime}, 51^{\circ} 24^{\prime} 3.8^{\prime \prime}$ & Triticale \\
3 & & Albic Luvisol & $22^{\circ} 36^{\prime} 51.8^{\prime \prime}, 51^{\circ} 21^{\prime} 27.0^{\prime \prime}$ & Wheat \\
4 & & Brunic Arenosol & $22^{\circ} 06^{\prime} 54.2^{\prime \prime}, 51^{\circ} 21^{\prime} 52.2^{\prime \prime}$ & Triticale \\
5 & & Brunic Arenosol & $22^{\circ} 15^{\prime} 19.0^{\prime \prime}, 51^{\circ} 23^{\prime} 0.9^{\prime \prime}$ & Oat \\
6 & & Brunic Arenosol & $22^{\circ} 15^{\prime} 55.5^{\prime \prime}, 51^{\circ} 23^{\prime} 1.9^{\prime \prime}$ & Oat \\
7 & & $2^{\circ} 04^{\prime} 0.3^{\prime \prime}, 50^{\circ} 51^{\prime} 15.81$ & Field prepared for seeding \\
8 & & Brunic Arenosol & $23^{\circ} 22^{\prime} 52.4^{\prime \prime}, 50^{\circ} 51^{\prime} 14.8^{\prime \prime}$ & Triticale \\
9 & & Brunic Arenosol & $22^{\circ} 07^{\prime} 29.9^{\prime \prime}, 51^{\circ} 25^{\prime} 5.5^{\prime \prime}$ & Strawberries \\
10 & & Brunic Arenosol & $23^{\circ} 42^{\prime} 56.6^{\prime \prime}, 50^{\circ} 44^{\prime} 48.3^{\prime \prime}$ & Triticale \\
11 & Hydrogenic Phaeozem & Mollic Gleysol & $22^{\circ} 06^{\prime} 18.8^{\prime \prime}, 51^{\circ} 22^{\prime} 48.0^{\prime \prime}$ & Colza \\
12 & $(11-14)$ & Mollic Gleysol & $22^{\circ} 01^{\prime} 25.5^{\prime \prime}, 51^{\circ} 29^{\prime} 15.3^{\prime \prime}$ & Wheat \\
13 & & Eutric Fluvisol & $21^{\circ} 59^{\prime} 10.1^{\prime \prime}, 51^{\circ} 33^{\prime} 47.7^{\prime \prime}$ & Oat \\
14 & & Eutric Histosol & $22^{\circ} 16^{\prime} 38,9^{\prime \prime} 51^{\circ} 25^{\prime} 27,3^{\prime \prime}$ & Oat \\
15 & & $23^{\circ} 10^{\prime} 58.3^{\prime \prime} 51^{\circ} 12^{\prime} 22.3^{\prime \prime}$ & Celeries \\
16 & Lithogenic & Rendzina Leptosol & $23^{\circ} 11^{\prime} 43.9^{\prime \prime} 51^{\circ} 12^{\prime} 10,8^{\prime \prime}$ & Oat \\
\hline
\end{tabular}


to $20{ }^{\circ} \mathrm{C}$; however, an average annual temperature for Lubelskie voivodeship usually does not exceed $10{ }^{\circ} \mathrm{C}$ (c.a. $7.3^{\circ} \mathrm{C}$ ), whereas an average annual rainfall amount to c.a. $560 \mathrm{~mm}$. Under laboratory conditions, each sample was passed through a $2.0-\mathrm{mm}$ sieve and shortly stored at $4{ }^{\circ} \mathrm{C}$ prior to the analysis.

Particle size distribution (PSD) was measured using a laser diffractometer Mastersizer 2000 (Malvern, UK) with Hydro G dispersion units [34, 35]. The soils were dispersed using ultrasound at $35 \mathrm{~W}$ for $4 \mathrm{~min}$ without removing the organic matter [34]. The measurements were carried out in three replications. PSD in the soils investigated, taking into account both the World Reference Base for soil resources (WRB) and the Polish Society of Soil Science (PSSS) classifications, are presented in Table 2. Soil moisture (MOIST) was determined by a gravimetric method $\left(24 \mathrm{~h}, 105^{\circ} \mathrm{C}\right)$.

The soil acidity $(\mathrm{pH})$ and electric conductivity (EC) were determined in triplicate from a 2:1 soil suspension in distilled water using a multifunctional potential metre (Hach Lange, Poland).

Easily degradable carbon (EDC), i.e. a measure of active forms of carbon available for microorganisms and plant roots, was determined in triplicate with the use of UV-1800 (Shimadzu) spectrophotometer $(\lambda=550 \mathrm{~nm})$, by $\mathrm{KMnO}_{4}$ digestion and expressed as milligrammes per kilogramme $[35$, 36].

The concentrations of nitrogen forms $\left(\mathrm{NH}_{4}-\mathrm{N}, \mathrm{NO}_{3}-\mathrm{N}\right.$, $\mathrm{NO}_{2}-\mathrm{N}$ ) were measured colorimetrically using an AutoAnalyser 3 System (Bran+Luebbe, Germany), according to the description by Wolińska et al. [37]. Each of the measurements was done in triplicate.

More details about the investigated soils and other physicochemical and biological factors are available in our previous studies [35, 37-39].

\section{DNA Extraction}

DNA was extracted within $24 \mathrm{~h}$ after sample collection according to the modified procedure elaborated for soil material as described by Tomczyk-Żak et al. [40]. The modification included an additional purification step by $\mathrm{CsCl}$ gradient centrifugation $\left(16 \mathrm{~h}, 70,000 \mathrm{rpm}, 20{ }^{\circ} \mathrm{C}\right.$; Sorvall WX Ultra ThermoScietific). More details about the DNA isolation procedure are available in Wolińska et al. [35]. The concentrations of the isolated DNA were quantified with a NanoDrop spectrophotometer (ThermoScientific) after 10-fold dilution, in triplicate.

\section{Next-Generation Sequencing}

To classify soil bacterial communities, amplification of the $16 \mathrm{~S}$ ribosomal RNA (rRNA) V3 region gene was carried out (27f, 518r). PCR conditions were as follows: $95^{\circ} \mathrm{C}$ for $3 \mathrm{~min}$, 30 cycles of $95^{\circ} \mathrm{C}$ for $30 \mathrm{~s}, 53^{\circ} \mathrm{C}$ for $30 \mathrm{~s}$ and $72^{\circ} \mathrm{C}$ for $1 \mathrm{~min}$, with a final extension at $72{ }^{\circ} \mathrm{C}$ for $7 \mathrm{~min}$. NGS of the metagenomic16S rRNA amplicons was performed with application of the Ion Torrent ${ }^{\mathrm{TM}}$ technology (Ion PGM ${ }^{\mathrm{TM}}$, Life Technologies). Amplicons were analysed using recommended
Table 2 Clay, silt and sand fractions (in volume percentage) obtained by Hydro $G$ unit of laser diffractometer Mastersizer 2000

\begin{tabular}{llllll}
\hline Sample no. & Loam $(\mathrm{mm})$ & Silt $(\mathrm{mm})$ & Sand $(\mathrm{mm})$ & \multicolumn{2}{l}{ Particle size group } \\
\cline { 5 - 6 } & $<0.002$ & $0.002-0.05$ & $0.05-2.0$ & WRB & PSSS \\
\hline 1 & 4.76 & 37.66 & 57.58 & Sandy loam & Sandy loam \\
2 & 1.25 & 17.28 & 81.47 & Sandy loam & Sandy loam \\
3 & 4.12 & 55.99 & 39.88 & Silt loam & Loamy silt \\
4 & 5.60 & 50.80 & 43.59 & Silt loam & Loamy silt \\
5 & 2.06 & 22.96 & 74.98 & Sandy loam & Sandy loam \\
6 & 3.64 & 30.88 & 65.47 & Sandy loam & Sandy loam \\
7 & 6.43 & 77.34 & 16.23 & Silt loam & Loamy silt \\
8 & 5.26 & 74.37 & 20.37 & Silt loam & Loamy silt \\
9 & 3.69 & 39.07 & 57.24 & Sandy loam & Sandy loam \\
10 & 5.26 & 77.14 & 17.60 & Silt loam & Loamy silt \\
11 & 8.00 & 79.68 & 12.32 & Silt loam & Loamy silt \\
12 & 7.18 & 32.3 & 60.52 & Sandy loam & Sandy loam \\
13 & 2.35 & 34.50 & 63.15 & Sandy loam & Sandy loam \\
14 & 1.74 & 35.05 & 63.20 & Sandy loam & Sandy loam \\
15 & 8.53 & 65.86 & 25.61 & Silt loam & Loamy silt \\
16 & 5.89 & 66.75 & 27.36 & Silt loam & Loamy silt \\
\hline
\end{tabular}

WRB World Reference Base for soil resources; PSSS Polish Society of Soil Science 
kits (Ion Plus Fragment Library Kit, RT-PCR Ion Universal Library Quantitation Kit, Ion PGM ${ }^{\mathrm{TM}}$ Template OT2 400 Kit, Qubit ${ }^{\mathrm{TM}}$ Fluorometric Quantitation). The sequencing step (Ion $318^{\mathrm{TM}}$ Chip Kit v2) was realised in the Laboratory of Microarray Analyses (IBB PAS, Warsaw) according to manufacturer's instructions.

\section{Bioinformatics and Statistical Analyses}

DNA sequencing data were analysed using MOTHUR v.1.34.4. [41]. The reads were dereplicated and aligned to the MOTHUR-formatted version of the Silva reference database (silva.nr_v119), as described by Quast et al. [42]. Chimeras were detected and removed using UCHIME implementation [43]. The sequences were clustered into OTUs based on a $99 \%$ similarity threshold. A total of $358,289 \mathrm{bp}$ bacterial sequences (for the $\mathrm{V} 3$ region) with an average read length of $154 \mathrm{bp}$ were generated across all samples, representing 18,870 OTUs. The taxonomical composition was presented on the interactive Krona Charts [44] based on Table 4 with the number of OTUs.

Additionally, all collected data were statistically processed by means of Statistica 9 PL (StatSoft, USA). The assumptions of parametric tests were checked with Shapiro-Wilk $W$ statistics and, if the assumptions were not met, $\ln (x+1)$ transformation was applied. The relationships between the numbers of OTUs and physicochemical variables were assessed by means of analysis of regression. First, the correlation matrix was constructed and followed by selection of significant correlations $(p<0.05)$. For the significant correlations, either Pearson's $r$ or Spearman's rho correlation coefficients were calculated depending on data normality.

\section{Results}

\section{Physicochemical Soil Properties}

Soil texture plays a key role in carbon storage and influences nutrient availability for microorganisms, thus PSD is one of the most important soil parameter crucial for microbiological activity. By comparison of the content of particular fractions, the tested soils were classified into two groups: sandy loam and silt loam/loamy silt (Table 2), due to the dominance of coarser fractions (silt and sand). The chemical characteristic of the soils are shown in Table 3. As shown, there are differences in the chemical features among the $\mathrm{C}$ and $\mathrm{A}$ sites. Arable soils, at the moment of sampling were characterised by usually lower moisture content (5.2-24.7\%) than control soils (7.1$31.03 \%$ ). Moreover, A soils posses acidic $\mathrm{pH}$ and by c.a. 22-45 \% lower EDC content, compared with the C soils, where higher $\mathrm{pH}$ was close to neutral and higher EDC amounts ranging from 575.4 to $1209 \mathrm{mg} / \mathrm{kg}$ were available for microorganisms. Taking into account EC and indirect salinity, it was found that the A soils had a higher EC level $\left(0.025-0.168 \mathrm{mS} / \mathrm{cm}^{3}\right)$ than the $\mathrm{C}$ soils $(0.020-0.080 \mathrm{mS} /$ $\mathrm{cm}^{3}$ ). However, for both sites, the EC value did not exceed $2 \mathrm{mS} / \mathrm{cm}^{3}$, which classifies the investigated soils in the low saline category. In the case of nitrogen, the nitrate form $\mathrm{NO}_{3}-$ $\mathrm{N}$ ) was dominant both in the $\mathrm{C}$ as A soils; however, its concentration was substantially higher in the agricultural soils $(2.99-77.2 \mathrm{mg} / \mathrm{kg}$ ), which resulted from fertilisation, than in the wastelands $(1.7-13.8 \mathrm{mg} / \mathrm{kg}$ ). Additionally, the $\mathrm{C}$ soils were characterised by higher ammonia nitrogen content $(0.02-4.94 \mathrm{mg} / \mathrm{kg})$ and nitrite nitrogen $(0.09-0.87 \mathrm{mg} / \mathrm{kg})$ in contrast to the A soils, where these $\mathrm{N}$ forms amounted to $0.01-0.43$ and $0.04-0.12 \mathrm{mg} / \mathrm{kg}$, respectively.

The content of the nitrogen forms in the three groups (autogenic, hydrogenic and lithogenic) of the $\mathrm{C}$ and A soils are presented in the Electronic Supplementary Material (Figs. S1 and S2, respectively). It should be stressed that the aforementioned $\mathrm{N}$ content refers to nitrogen pool that remains in soil after the former vegetation season (2013), as the soils were sampled before fertilisation (early spring 2014). It was found that the highest concentrations of the $\mathrm{N}$ forms were accumulated in the agriculturally exploited RL soils belonging to the lithogenic group (Fig. S1), which significantly differed from the two other groups with respect to $\mathrm{NO}_{3}-\mathrm{N}$ and $\mathrm{NO}_{2}-\mathrm{N}$ $(p=0.0000)$. Taken into account the $\mathrm{NH}_{4}-\mathrm{N}$ pool, no differences were noted between the lithogenic and hydrogenic soils; however, there was a significant difference between the autogenic and lithogenic soils $(p=0.001)$, where $\mathrm{NH}_{4}-\mathrm{N}$ reached an $80 \%$ higher level in the lithogenic soils than in the autogenic (Fig. S1). The RL wasteland soils (Fig. S2) also contained significantly higher $\mathrm{NO}_{3}-\mathrm{N}$ content (c.a. by $43 \%$ ) than the autogenic and hydrogenic soils $(p=0.0023)$. There was a significant dominance of $\mathrm{NO}_{2}-\mathrm{N}(p=0.0018)$ in the controls of the autogenic soils, as in the case of $\mathrm{NH}_{4}-\mathrm{N}$, but the ammonium concentration did not differ significantly among the three soil groups ( $p=0.2932$, Fig. S2).

Deliberations concerning the $\mathrm{N}$ content in the different soil types are important from the point of prediction of the mineral fertilisation requirement. Thus, the effect of the land use on the content of the $\mathrm{N}$ form content in the autogenic (Fig. S3), hydrogenic (Fig. S4) and lithogenic soils (Fig. S5) was also investigated. In autogenic soils, represented by AL, BA and HP soils (Fig. S3), agricultural practices resulted in significant increase (c.a. by $60 \%$ ) of $\mathrm{NO}_{3}-\mathrm{N}(p=0.0000)$ in comparison with controls and in 3-fold decrease of $\mathrm{NO}_{2}-\mathrm{N}(p=0.0000)$ and $\mathrm{NH}_{4}-\mathrm{N}$ $(p=0.0000)$. Agricultural hydrogenic soils, represented by ML, EF and EH soil types (Fig. S4) also have higher pools of $\mathrm{NO}_{3}-\mathrm{N}$ and $\mathrm{NH}_{4}-\mathrm{N}$ than their corresponding controls; however, those differences were insignificant ( $p=0.0684$ and $p=0.0747$, respectively). According to $\mathrm{NO}_{2}-\mathrm{N}$ concentrations, no differences was stated between 
Table 3 Chemical soil features with respect to control (C) and agricultural (A) soils from Lubelskie voivodeship $( \pm \mathrm{SD})$

\begin{tabular}{|c|c|c|c|c|c|c|c|}
\hline & MOIST (\%) & $\mathrm{pH}\left(\mathrm{H}_{2} \mathrm{O}\right)$ & $\mathrm{EC}\left(\mathrm{mS} / \mathrm{cm}^{3}\right)$ & $\mathrm{EDC}(\mathrm{mg} / \mathrm{kg})$ & $\mathrm{NH}_{4}-\mathrm{N}(\mathrm{mg} / \mathrm{kg})$ & $\mathrm{NO}_{3}-\mathrm{N}(\mathrm{mg} / \mathrm{kg})$ & $\mathrm{NO}_{2}-\mathrm{N}(\mathrm{mg} / \mathrm{kg})$ \\
\hline \multicolumn{8}{|c|}{$\mathrm{C}$ soils } \\
\hline $1 \mathrm{C}$ & $9.76 \pm 0.11$ & $6.27 \pm 0.005$ & $0.034 \pm 0.003$ & $716.60 \pm 0.001$ & $0.09 \pm 0.006$ & $1.68 \pm 0.014$ & $0.17 \pm 0.001$ \\
\hline $2 \mathrm{C}$ & $11.16 \pm 0.11$ & $5.020 \pm 02$ & $0.029 \pm 0.002$ & $576.52 \pm 1.90$ & $0.04 \pm 0.014$ & $5.84 \pm 0.03$ & $0.10 \pm 0.001$ \\
\hline $3 \mathrm{C}$ & $9.13 \pm 0.05$ & $6.22 \pm 0.09$ & $0.054 \pm 0.005$ & $799.78 \pm 1.90$ & $0.06 \pm 0.006$ & $3.58 \pm 0.09$ & $0.42 \pm 0.005$ \\
\hline $4 \mathrm{C}$ & $13.50 \pm 0.10$ & $7.08 \pm 0.06$ & $0.062 \pm 0.002$ & $947.52 \pm 1.90$ & $0.48 \pm 0.008$ & $7.57 \pm 0.32$ & $0.53 \pm 0.003$ \\
\hline $5 \mathrm{C}$ & $8.63 \pm 0.15$ & $5.58 \pm 0.04$ & $0.049 \pm 0.001$ & $828.23 \pm 0.002$ & $0.69 \pm 0.009$ & $10.18 \pm 0.14$ & $0.21 \pm 0.002$ \\
\hline $6 \mathrm{C}$ & $8.63 \pm 0.15$ & $5.58 \pm 0.04$ & $0.049 \pm 0.001$ & $828.23 \pm 0.002$ & $0.69 \pm 0.009$ & $10.18 \pm 0.14$ & $0.21 \pm 0.002$ \\
\hline 7C & $12.76 \pm 0.11$ & $6.99 \pm 0.03$ & $0.065 \pm 0.001$ & $1113.9 \pm 0.001$ & $0.41 \pm 0.008$ & $5.41 \pm 0.14$ & $0.87 \pm 0.003$ \\
\hline $8 \mathrm{C}$ & $20.26 \pm 0.63$ & $6.06 \pm 0.009$ & $0.058 \pm 0.006$ & $919.07 \pm 1.90$ & $2.61 \pm 0.04$ & $11.07 \pm 0.05$ & $0.24 \pm 0.02$ \\
\hline $9 \mathrm{C}$ & $7.10 \pm 0.17$ & $5.40 \pm 0.006$ & $0.080 \pm 0.001$ & $575.42 \pm 0.001$ & $0.18 \pm 0.001$ & $1.76 \pm 0.06$ & $0.80 \pm 0.002$ \\
\hline $10 \mathrm{C}$ & $31.03 \pm 0.23$ & $7.22 \pm 0.02$ & $0.059 \pm 0.006$ & $1209.0 \pm 3.28$ & $0.02 \pm 0.002$ & $8.23 \pm 0.02$ & $0.44 \pm 0.006$ \\
\hline $11 \mathrm{C}$ & $14.33 \pm 0.57$ & $6.76 \pm 0.01$ & $0.040 \pm 0.002$ & $1051.5 \pm 3.28$ & $0.78 \pm 0.01$ & $10.06 \pm 0.09$ & $0.15 \pm 0.001$ \\
\hline $12 \mathrm{C}$ & $10.40 \pm 0.17$ & $6.25 \pm 0.03$ & $0.044 \pm 0.002$ & $795.40 \pm 0.001$ & $4.94 \pm 0.008$ & $6.75 \pm 0.05$ & $0.10 \pm 0.001$ \\
\hline $13 \mathrm{C}$ & $8.86 \pm 0.11$ & $5.64 \pm 0.06$ & $0.025 \pm 0.001$ & $620.29 \pm 1.90$ & $0.27 \pm 0.03$ & $2.20 \pm 0.05$ & $0.13 \pm 0.002$ \\
\hline $14 \mathrm{C}$ & $9.30 \pm 0.20$ & $5.27 \pm 0.01$ & $0.020 \pm 0.001$ & $877.48 \pm 0.001$ & $0.02 \pm 0.002$ & $9.05 \pm 0.03$ & $0.09 \pm 0.001$ \\
\hline $15 \mathrm{C}$ & $12.50 \pm 0.17$ & $5.76 \pm 0.01$ & $0.040 \pm 0.002$ & $693.62 \pm 0.001$ & $3.39 \pm 0.06$ & $10.12 \pm 0.07$ & $0.09 \pm 0.004$ \\
\hline $16 \mathrm{C}$ & $19.30 \pm 0.17$ & $7.39 \pm 0.02$ & $0.070 \pm 0.001$ & $1104.0 \pm 0.001$ & $0.28 \pm 0.02$ & $13.82 \pm 0.5$ & $0.13 \pm 0.004$ \\
\hline \multicolumn{8}{|c|}{ A soils } \\
\hline $1 \mathrm{~A}$ & $8.20 \pm 0.20$ & $5.23 \pm 0.06$ & $0.045 \pm 0.08$ & $544.78 \pm 1.90$ & $0.01 \pm 0.006$ & $9.34 \pm 0.8$ & $0.11 \pm 0.003$ \\
\hline $2 \mathrm{~A}$ & $9.30 \pm 0.10$ & $4.66 \pm 0.02$ & $0.033 \pm 0.09$ & $460.51 \pm 0.01$ & $0.02 \pm 0.001$ & $7.37 \pm 0.05$ & $0.08 \pm 0.001$ \\
\hline $3 \mathrm{~A}$ & $10.22 \pm 0.03$ & $4.78 \pm 0.02$ & $0.130 \pm 0.08$ & $511.95 \pm 1.90$ & $0.01 \pm 0.001$ & $53.32 \pm 0.52$ & $0.05 \pm 0.005$ \\
\hline $4 \mathrm{~A}$ & $12.56 \pm 0.06$ & $6.98 \pm 0.02$ & $0.065 \pm 0.09$ & $762.57 \pm 0.02$ & $0.43 \pm 0.006$ & $18.25 \pm 0.06$ & $0.10 \pm 0.004$ \\
\hline $5 \mathrm{~A}$ & $6.60 \pm 0.10$ & $5.45 \pm 0.04$ & $0.050 \pm 0.09$ & $623.58 \pm 1.90$ & $0.07 \pm 0.006$ & $25.53 \pm 0.18$ & $0.12 \pm 0.001$ \\
\hline $6 \mathrm{~A}$ & $9.23 \pm 0.06$ & $4.78 \pm 0.006$ & $0.063 \pm 0.09$ & $557.91 \pm 1.90$ & $0.01 \pm 0.007$ & $20.26 \pm 0.07$ & $0.09 \pm 0.004$ \\
\hline $7 \mathrm{~A}$ & $12.13 \pm 0.15$ & $6.93 \pm 0.006$ & $0.130 \pm 0.001$ & $536.03 \pm 0.01$ & $0.05 \pm 0.001$ & $14.48 \pm 0.04$ & $0.04 \pm 0.005$ \\
\hline $8 \mathrm{~A}$ & $19.00 \pm 0.17$ & $5.96 \pm 0.12$ & $0.077 \pm 0.10$ & $661.88 \pm 1.90$ & $0.36 \pm 0.02$ & $17.35 \pm 0.03$ & $0.12 \pm 0.002$ \\
\hline $9 \mathrm{~A}$ & $5.66 \pm 0.11$ & $5.13 \pm 0.006$ & $0.373 \pm 0.11$ & $507.57 \pm 3.79$ & $0.19 \pm 0.009$ & $4.96 \pm 0.06$ & $0.14 \pm 0.001$ \\
\hline $10 \mathrm{~A}$ & $24.66 \pm 0.28$ & $6.61 \pm 0.05$ & $0.123 \pm 0.05$ & $670.64 \pm 0.001$ & $0.02 \pm 0.001$ & $27.43 \pm 0.08$ & $0.09 \pm 0.003$ \\
\hline $11 \mathrm{~A}$ & $12.96 \pm 0.28$ & $6.73 \pm 0.006$ & $0.119 \pm 0.05$ & $608.26 \pm 0.002$ & $0.41 \pm 0.04$ & $10.11 \pm 0.07$ & $0.13 \pm 0.004$ \\
\hline $12 \mathrm{~A}$ & $5.80 \pm 0.17$ & $4.74 \pm 0.02$ & $0.048 \pm 0.05$ & $526.18 \pm 0.001$ & $0.03 \pm 0.004$ & $21.90 \pm 0.02$ & $0.09 \pm 0.001$ \\
\hline $13 \mathrm{~A}$ & $5.20 \pm 0.17$ & $4.18 \pm 0.05$ & $0.038 \pm 0.11$ & $496.63 \pm 0.001$ & $0.14 \pm 0.04$ & $2.99 \pm 0.03$ & $0.09 \pm 0.001$ \\
\hline $14 \mathrm{~A}$ & $6.50 \pm 0.10$ & $4.85 \pm 0.03$ & $0.022 \pm 0.06$ & $833.16 \pm 0.001$ & $0.01 \pm 0.001$ & $10.22 \pm 0.12$ & $0.08 \pm 0.002$ \\
\hline $15 \mathrm{~A}$ & $10.86 \pm 0.11$ & $5.58 \pm 0.06$ & $0.168 \pm 0.05$ & $611.54 \pm 0.001$ & $0.05 \pm 0.01$ & $77.17 \pm 0.14$ & $0.08 \pm 0.007$ \\
\hline $16 \mathrm{~A}$ & $12.80 \pm 0.10$ & $5.58 \pm 0.11$ & $0.113 \pm 0.05$ & $550.25 \pm 1.90$ & $0.22 \pm 0.01$ & $32.98 \pm 0.27$ & $0.09 \pm 0.001$ \\
\hline
\end{tabular}

A and C sites $(p=0.8284)$. Agricultural soil usage strongly affected lithogenic group, represented by RL soil type (Fig. S5) and resulted in higher (c.a. by $80 \%$ ) level of $\mathrm{NO}_{3}-\mathrm{N}(p=0.0015)$ and $\mathrm{NH}_{4}-\mathrm{N}(p=0.0432)$ than in controls, whereas $\mathrm{NO}_{2}-\mathrm{N}$ remained on similar level in agricultural and control sites $(p=0.0654)$.

DNA quantification is presented in Table S1 (see Electronic Supplementary Material). It was found that higher DNA content characterised C soils and amounted to 1.275$7.128 \mu \mathrm{g} / \mathrm{g}$, whereas in A soils ranged from 0.834 to $3.835 \mu \mathrm{g} /$ g. However, positive results of PCR were achieved independently on DNA content in every soil samples.

\section{Diversity of Potential Nitrogen-Fixing Bacteria in Autogenic, Hydrogenic and Lithogenic Soils}

A total of 358,289 valid reads were obtained from 31 samples (together $\mathrm{C}$ and $\mathrm{A}$ soil samples) by Ion Torrent ${ }^{\mathrm{TM}}$ technology. Microbiome of A soils were represented by 21,366 OTUs classified as Proteobacteria, Acidobacteria, Actinobacteria, Bacteroidetes, Elusimicrobia, Firmicutes, Chlorobi, Chloroflexi, Gemmatimonadetes, Planctomycetes, Spirochaeta and Verrucomicrobia, whilst with respect to controls, higher by $6.07 \%$ OTU number were noted and amounted to 22,664 . However, by taking into account the 
number of $\alpha$-Proteobacteria, $\beta$-Proteobacteria and Cyanobacteria OTUs, it was found that A soils contained 6625 identified OTUs whilst C soils 6902 OTUs, and among them, a total of 387-392 OTUs were classified as PNF bacteria, for $\mathrm{C}$ and A soils, respectively (Table 4). The highest number of PNF bacterial diversity (194-213 OTUs, for C and A) were noted in autogenic group of soils, then in hydrogenic (134-168 OTUs, for A and C) and the lowest in lithogenic soils (23-27 OTUs, for A and C variant).

In general, the investigated Polish arable soils were decidedly dominated by $\beta$-Proteobacteria representatives of PNF bacteria (183 and 193 OTUs, for C and A, respectively). In this class, Burkholderiaceae family and Burkholderia genus were the most important (Table 4). Representatives of Burkholderia usually preferred A sites belonging to autogenic and hydrogenic soils (54 and 26 OTUs, respectively). Quite high Burkholderia numbers were also found in $\mathrm{C}$ sites (48 and 23 OTUs), assigned for the following autogenic and hydrogenic soils. In contrary, lithogenic soils constituted the least-preferred niches for Burkholderia inhabitants (4-5 OTUs). Subdominants of $\beta$-Proteobacteria were Cupriavidus representatives which demonstrated similar to Burkholderia preferences for niche occupation (Table 4).

Table 4 General number of $\alpha$-Proteobacteria, $\beta$-Proteobacteria and Cyanobacteria OTUs and PNF bacteria in the three groups of control (C) and agricultural (A) soils

\begin{tabular}{|c|c|c|c|c|c|c|}
\hline \multirow[t]{3}{*}{ Phylogenetic group } & \multicolumn{6}{|c|}{ OTU number } \\
\hline & \multicolumn{2}{|c|}{ Lithogenic soil } & \multicolumn{2}{|c|}{ Autogenic soil } & \multicolumn{2}{|c|}{ Hydrogenic soi } \\
\hline & $\mathrm{C}$ & A & $\mathrm{C}$ & A & $\mathrm{C}$ & A \\
\hline \multicolumn{7}{|l|}{ Proteobacteria } \\
\hline$\alpha$-Proteobacteria & $172^{\mathrm{a}}$ & $474^{\mathrm{a}}$ & $1720^{\mathrm{a}}$ & $1906^{\mathrm{a}}$ & $520^{\mathrm{a}}$ & $557^{\mathrm{a}}$ \\
\hline Rhizobaceae & $5^{\mathrm{a}}$ & $6^{\mathrm{a}}$ & $22^{\mathrm{a}}$ & $23^{\mathrm{a}}$ & $35^{\mathrm{a}}$ & $10^{\mathrm{a}}$ \\
\hline Rhizobium & $1^{\mathrm{b}}$ & $2^{b}$ & $5^{\mathrm{b}}$ & $5^{\mathrm{b}}$ & $3^{\mathrm{b}}$ & $2^{\mathrm{b}}$ \\
\hline Hyphomicrobiaceae & $16^{\mathrm{a}}$ & $10^{\mathrm{a}}$ & $62^{\mathrm{a}}$ & $69^{\mathrm{a}}$ & $110^{\mathrm{a}}$ & $24^{\mathrm{a}}$ \\
\hline Devosia & $4^{\mathrm{b}}$ & $3^{\mathrm{b}}$ & $16^{\mathrm{b}}$ & $16^{\mathrm{b}}$ & $9^{\mathrm{b}}$ & $7^{\mathrm{b}}$ \\
\hline Methylobacteraceae & $1^{\mathrm{a}}$ & $1^{\mathrm{a}}$ & $2^{\mathrm{a}}$ & $4^{\mathrm{a}}$ & $5^{\mathrm{a}}$ & $3^{\mathrm{a}}$ \\
\hline Microvirga & $1^{\mathrm{b}}$ & $1^{\mathrm{b}}$ & $1^{\mathrm{b}}$ & $4^{\mathrm{b}}$ & $2^{\mathrm{b}}$ & $2^{\mathrm{b}}$ \\
\hline Methylobacterium & $0^{\mathrm{b}}$ & $0^{\mathrm{b}}$ & $1^{\mathrm{b}}$ & $0^{\mathrm{b}}$ & $3^{\mathrm{b}}$ & $1^{\mathrm{b}}$ \\
\hline Phyllobacteraceae & $4^{\mathrm{a}}$ & $3^{\mathrm{a}}$ & $9^{\mathrm{a}}$ & $13^{\mathrm{a}}$ & $18^{\mathrm{a}}$ & $4^{\mathrm{a}}$ \\
\hline Mesorhizobium & $2^{\mathrm{b}}$ & $1^{\mathrm{b}}$ & $8^{\mathrm{b}}$ & $9^{\mathrm{b}}$ & $4^{\mathrm{b}}$ & $4^{\mathrm{b}}$ \\
\hline Phyllobacterium & $0^{\mathrm{b}}$ & $0^{\mathrm{b}}$ & $0^{\mathrm{b}}$ & $0^{\mathrm{b}}$ & $1^{\mathrm{b}}$ & $0^{\mathrm{b}}$ \\
\hline$\beta$-Proteobacteria & $335^{\mathrm{a}}$ & $768^{\mathrm{a}}$ & $2527^{\mathrm{a}}$ & $2765^{\mathrm{a}}$ & $1062^{\mathrm{a}}$ & $756^{\mathrm{a}}$ \\
\hline Burkholderiaceae & $13^{\mathrm{b}}$ & $8^{\mathrm{b}}$ & $92^{\mathrm{b}}$ & $97^{b}$ & $114^{\mathrm{b}}$ & $74^{\mathrm{b}}$ \\
\hline Burkholderia & $5^{b}$ & $4^{b}$ & $48^{\mathrm{b}}$ & $54^{\mathrm{b}}$ & $23^{\mathrm{b}}$ & $26^{\mathrm{b}}$ \\
\hline Cupriavidus & $0^{\mathrm{b}}$ & $2^{\mathrm{b}}$ & $8^{\mathrm{b}}$ & $11^{\mathrm{b}}$ & $7^{\mathrm{b}}$ & $4^{b}$ \\
\hline Cyanobacteria & $1^{\mathrm{b}}$ & $2^{\mathrm{b}}$ & $15^{\mathrm{b}}$ & $17^{\mathrm{b}}$ & $2^{\mathrm{b}}$ & $14^{\mathrm{b}}$ \\
\hline
\end{tabular}

${ }^{\text {a }}$ General number of OTUs noted in the current study

${ }^{\mathrm{b}}$ OTUs dedicated for PNF bacteria
Among PNF bacterial OTUs assigned to $\alpha$-Proteobacteria, the domination of Hyphomicrobiaceae representatives was noted and among them Devosia were the most abundant (16 OTUs in autogenic soils, 7-9 OTUs in hydrogenic and 3-4 OTUs in lithogenic soils). Subdominants were Rhizobiaceae and Phyllobacteriaceae families with Rhizobium, Mesorhizobium and Phyllobacterium representatives, respectively. Generally, among each of the main PNF phyla, higher OTU number was noted in autogenic rather than in hydrogenic and finally lithogenic groups of soils, which suggests that soil formation process is a conducive factor for PNF bacteria preference for soil niche occupation.

As presented in Fig. 2a, the PNF bacterial community structure depended both on soil formation process as on the way of land use. Anyhow, from 31 investigated sites (A and C), eight important genera of PNF bacteria were identified, among which Devosia, Mesorhizobium, Burkholderia and Cupriavidus were classified according to OTU numbers as dominant PNF bacteria (Fig. 2b). The same, those genera with OTUs $<10$ were characterised as subdominants of PNF bacteria in Polish soils (Fig. 2c). Usually, OTU numbers were higher in A soils in respect to Burkholderia, Cupriavidus, Mesorhizobium and Microvirga or remained on similar level with C soils with respect to Mesorhizobium and Rhizobium representatives. Significant decrease of OTUs number as a consequence of soil agricultural exploitation was noted in relation to Devosia and Methylobacterium, whereas the presence of Phyllobacterium was stated only in C soils.

As was earlier mentioned the seven investigated soil types were classified into the three groups according to their origin (bedrock formation): lithogenic, autogenic and hydrogenic. Our result clearly demonstrated that not only way of land use (cultivation or non-cultivation) but also soil formation process is an important factor for subsequent microbial PNF bacteria diversity colonisation preferences. Decidedly, the highest number of PNF bacteria were found in autogenic group represented by $\mathrm{AL}, \mathrm{BA}$ and HP soil types, with domination of Proteobacteria (87 and 99 OTUs for C and A soils, respectively) and among them Burkholderia genus (48 and 54 OTUs). Likewise, the number of Cyanobacteria were the highest in autogenic A soils (17 OTUs) than C sites (15 OTUs). This trend was also supported with respect to subdominant PNF bacterial OTUs that also reached the highest abundance in autogenic soils with considerable (c.a. $20 \%$ ) surplus of Rhizobium on the background of other identified genera (Fig. 2c). Microvirga representatives subdominated in the agricultural autogenic soils whilst in controls its abundance decreased by $25 \%$. On the contrary, $\mathrm{C}$ autogenic soils contained representatives of Methylobacterium whilst in A soils mentioned genus was not detected. 
Fig. 2 The main phyla of PNF bacteria (a), dominant Proteobacteria OTUs (b) and subdominant Proteobacteria OTUs (c) in the three groups of control (c) and agricultural (a) soils. Mean values with standard error (SE) are presented
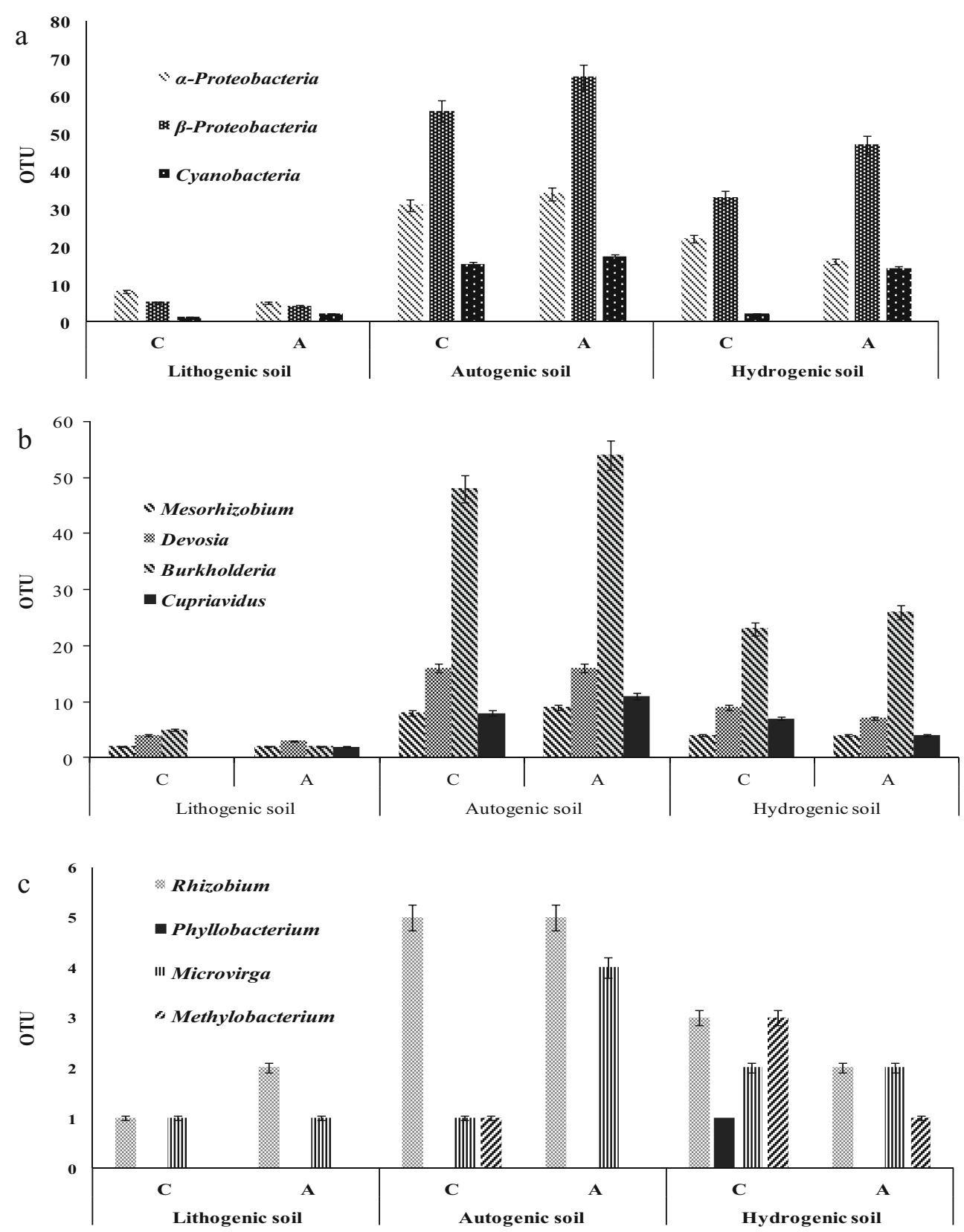

The microbiome of hydrogenic soils, represented by MG, $\mathrm{EF}$ and $\mathrm{EH}$ soil types (both $\mathrm{C}$ and $\mathrm{A}$ ) were definitely lower than those of autogenic soils, anyhow also Proteobacteria dominance was stated (52 and 46 OTUs for C and A sites) with predomination of Burkholderia (23 and 26 OTUs). Subdominant OTUs of PNF bacteria in C hydrogenic soils were formed by Rhizobium, Methylobacterium, Microvirga and Phyllobacterium whilst in A soils mentioned OTU number were reduced by c.a. 30 and $66 \%$ for Rhizobium and Methylobacterium, respectively. Microvirga OTU number remained on the same level regardless of the way the soil was used, whereas Phyllobacterium was not present in agricultural hydrogenic soils.
However, the lowest level of PNF bacterial community abundance were observed with respect to lithogenic soils, represented by RL soil type, which testifies that those soil categories are not optimal niches for PNF bacteria development. Rhizobium population was reduced by $20-40 \%$ than its OTU number noted in hydrogenic or autogenic soils, respectively, whereas Microvirga remained on the same level both on $\mathrm{C}$ and $\mathrm{A}$ soils. It should be underlined that in the lithogenic group of soil, the presence of Methylobacterium and Phyllobacterium has not been detected. In order to determine the preferable conditions for living in soil environment of PNF bacteria, the relationships among soil features and bacterial OTUs were tested. 


\section{Ecological Characteristic of Potential Niches for Nitrogen-Fixing Bacteria}

The significant relationships between $\mathrm{pH}$ and the bacterial community of PNF have been demonstrated in all type of soils. It was found that the abundance of Burkholderia significantly decreased with the acidic $\mathrm{pH}$, below 5.5 (respectively LG: $p<0.05, \rho=-0.196$; AG: $p<0.05, \rho=-0.538$; and HG: $p<0.05, \rho=-0.852$; Table 5), which suggests that PNF bacteria prefer rather higher $\mathrm{pH}$ values, close to the neutral conditions or even alkaline than acidic. The same phenomenon has been shown in relation to the abundance of Cupriavidus. The negative significant correlation between $\mathrm{pH}$ and the number of OTUs were found in the AG and LG soils (LG: $p<0.05, \rho=-0.361$; AG: $p<0.05, \rho=-0.471)$. The situation is unlike in the HG soils, where the positive correlation between $\mathrm{pH}$ and the number of OTUs $(p<0.05, \rho=0.219)$ were demonstrated. Probably, this is connected with the naturally low $\mathrm{pH}$ of the HG soils (Table 3). No correlation between $\mathrm{pH}$ and the abundance of Mesorhizobium was found, except for the LG soils $(p<0.05, \rho=0.398)$. Soil $\mathrm{pH}$ also indicates some negative effects on the abundance of Cyanobacteria (LG: $p<0.05, \rho=-0.994$; AG: $p<0.05, \rho=-0.441$; HG: $p<0.05, \rho=-0.466)$. The $\mathrm{pH}$ of these soils was slightly acidic (c.a. 5.51), and much lower than the optimum $\mathrm{pH}(7-10)$.

Also, soil moisture influenced the PNF bacteria community (Table 5). Positive correlations were noted between MOIST and OTU number inhabiting AG soils and belonging to the following genera: Cupriavidius $(p<0.05, \rho=0.215)$, Mesorhizobium $(p<0.05, \rho=0.341)$, Devosia $(p<0.05$, $\rho=-0.109)$ and Rhizobium $(p<0.05, \rho=0.120)$. The last two displayed positive relationship also with respect to $\mathrm{HG}$ soils $(p<0.05, \rho=0.963$ and $\rho=0.405)$, respectively. The increase of MOIST was also optimal to Microvirga-inhabiting HG soils $(p<0.05, \rho=0.773$. However, Burkholderia, Methylobacterium and Cyanobacteria being present in AG and HG soils preferred rather dry soil conditions and displayed negative correlations with MOIST as presented in Table 5.

Carbon (especially its easily available form) was an important limitation factor for PNF bacterial growth. We obtained significant negative correlation between EDC and OTU number with respect to Burkholderia, Cupriavidus, Devosia and Rhizobium ( $p<0.05, \rho=-0.2199$ and $p<0.05, \rho=-0.397$ ), which means that those PNF bacteria are the most sensitive on EDC supply. A similar trend was observed for the abundance of Cyanobacteria and EDC value ( $p<0.05$; LG: $\rho=-0.994$; AG: $\rho=-0.284$; HG: $\rho=-0.684$ ), which indicated that the microorganisms belonging to this phylum are significantly EDC dependent. Moreover, it seems that EC can considerably modulate the OTU number of PNF bacteria. We showed a positively correlated EC value and the number of OTU for Burkholderia (only for AG soils, $p<0.05$, LG: $\rho=0.389$ ),
Cupriavidus, Mesorhizobium, Devosia (only for LG soils, respectively, $p<0.05$; LG: $\rho=-0.994, \rho=-0.331$, $\rho=-0.331$ ), Rhizobium, Microvirga and Cyanobacteria.

The nitrogen content $\left(\mathrm{NO}_{2}-\mathrm{N}, \mathrm{NO}_{3}-\mathrm{N}, \mathrm{NH}_{4}-\mathrm{N}\right)$ has a different impact on the number of PNF bacteria OTUs. It was shown that there are positive correlation between the abundance of Microvirga in soils and the nitrogen content (Table 5). The OTU number of Cyanobacteria can also be modified by their $\mathrm{NO}_{2}-\mathrm{N}, \mathrm{NO}_{3}-\mathrm{N}$ and $\mathrm{NH}_{4}-\mathrm{N}$ contents (Table 5).

\section{Discussion}

To date, majority of studies related to nitrogen-fixing bacteria were concentrated on symbiosis between them and different legumes [2, 26]. Anyhow, there is a lack of knowledge about PNF bacterial groups, inhabiting agricultural soils, which may not be under symbiosis relation with legumes but are present in the soil environment and able to perform potential nitrogen fixation process. Moreover, the novelty of our study is to demonstrate that soil formation process is a crucial factor for PNF bacterial diversity in with regard to Polish agricultural and control soils. Here, we analysed the biodiversity of PNF bacteria with application of NGS technique through which the shortage and limitation connected with detecting only the most abundant and cultivated genera were omitted. Besides precise recognition of PNF bacterial diversity in agricultural soils and wastelands, optimal niche conditions were also determined.

We found the operational taxonomic units assigned to freeliving (Cyanobacteria) and potential plant-associated nitrogen-fixing bacteria (Burkholderia, Devosia, Cupriavidus and Rhizobium). It should be noted that OTUs are a proxy for potential bacterial activity but do not reveal the nature of the bacterial activity. Presumably, the high relative abundance belonging to the PNF bacteria can indicate that the activity of nitrogen-fixing bacteria may be of ecological importance at the study site, especially in agricultural soil.

Determination of $\mathrm{N}$ contents in agricultural soils in spring is a useful tool to assess requirements for nitrogen fertilisation, whilst the distribution of $\mathrm{NO}_{3}-\mathrm{N}$ in soil in autumn evaluates possible nitrogen losses by leaching during winter [16]. It was also assumed that soil agricultural practices influence the activity of microorganisms which participate in various nitrogen transformation processes in soil [45]. Importantly, our results reflect similarity of soil science classification with respect to soil formation processes and microbial biodiversity evolution and colonisation preferences. It seems that the lithogenic soils with lowest abundance of PNF revealed their need for mineral fertilisation by adding additional nitrogen compounds. Although this soil group contained the highest N pool (remaining after last vegetation season) among each investigated 
soils (Figs. S1 and S5), it turned out to be the most requiring and most sensitive of $\mathrm{N}$ content, and thus rational fertilisation of RL soils is reasonable. Moreover, the obtained results suggested that the autogenic and hydrogenic soils have enough abundance of PNF, especially when considering lack of significant differences in the number of OTUs between agricultural and control soils.

The dominant Burkholderia genus achieved higher abundance by 70 and $87 \%$ in hydrogenic and autogenic soils, respectively, than in lithogenic soils. The same abundance of Devosia was by 55 and $70 \%$ higher for hydrogenic and autogenic soils with regard to lithogenic. Thus, it may be suspected that both autogenic as hydrogenic soils do not require additional fertilisation because they are able to use the $\mathrm{N}$ resources accumulated in the ground and this $\mathrm{N}$ pool is sufficient for inhabiting PNF bacteria. Furthermore, the results from Wood et al.'s [46] study suggest that soil bacterial diversity decreased with mineral fertiliser addition. These authors recommended fertilisation by combining mineral fertilisers with organic inputs. It seems that this fertilisation strategy is appropriate for Polish lithogenic soils. The suitable fertilisation and another way of land use as well as concern for beneficial soil microflora may have an impact in soil ecosystem functionality, especially with respect to agriculture. Comparable results were demonstrated by Montecchia et al. [47], who studied changes in soil bacterial communities after conversion of the Yungas forests to agriculture. Their results indicated that communities with many taxa (especially the relative abundance of copiotrophic and oligotrophic taxa) may have many functional attributes, allowing to maintain at least some soil ecosystem services after forest conversion to croplands.

It was assumed that the PNF bacteria population could be affected by a number of different chemical and biological factors. Among them, impact of $\mathrm{pH}$ [48], soil moisture [49], carbon and nitrogen content $[1,50], \mathrm{EC}[50]$ and total phosphorus [51] are the most known and described. Significant impact of $\mathrm{pH}$, moisture, carbon and nitrogen concentrations and $\mathrm{EC}$ were also demonstrated in the current study. Bartram et al. [48] reported that bacterial diversity is the lowest in acidic $\mathrm{pH}$ and displayed increasing trend with increase $\mathrm{pH}$ values. They also determined optimal $\mathrm{pH}$ (7.5) for maintaining biodiversity. However, there are some species of bacteria for which $\mathrm{pH}$ is not a limiting factor. One of them is bacteria belonging to Mesorhizobium. In the literature, strains which can grow at $\mathrm{pH}$ values ranging between 4.5 and 10.5 , for example Mesorhizobium shonense [52] are known. The analogical situations exist for the abundance of Devosia and Rhizobium. For Methylobacterium, optimal growth conditions are reported to be close to neutrality, although some strains can grow at $\mathrm{pH} 4$ and some at $\mathrm{pH} 10$. Therefore, our results indicate only a correlation between $\mathrm{pH}$ of HG soils and the abundance of Methylobacterium. 
Obtained results were compared with those of other researchers and summarised in Table 6. Investigated Polish soils were characterised by the lowest $\mathrm{pH}$ values which in the case of arable soils was acidic $(\mathrm{pH} 5.51)$ and one unit higher $(\mathrm{pH}$ 6.15) with respect to wastelands used as controls. As the impact of $\mathrm{pH}$ on PNF bacteria is known to be the most significant, global soils were classified according to $\mathrm{pH}$ value, dominant phyla and predominant genera of nitrogen-fixing bacteria. In those conditions, populations of PNF bacteria were classified as Proteobacteria phylum ( $\alpha$ - and $\beta$-classes) with domination of the Burkholderia genus both in A and $\mathrm{C}$ soils. By comparison, the $\mathrm{pH}$ values of other global soils stated that those from Antarctica region had alkaline $\mathrm{pH}$ (8.5-9.9) and the dominant phylum was Cyanobacteria and Proteobacteria with Geobacter as predominant genus [53]. Soils with $\mathrm{pH}$ close to neutral (6.7) from the Arctic tundra and scrubland soils were dominated by Rhodopseudomonas genus [54, 55], whereas those with $\mathrm{pH}$ higher than 7 by Methylocella [56] and Bradyrhizobium [25] for Tibetan prairie soil and Quilian meadows, respectively.

Domination of Bradyrhizobium with respect to Amazon soils under agroforestry system (Cowpea grain-producing legume) was reported by Jaramillo et al. [10]. Specific nitrogenfixing microbiome of switchgrass that is native to the tallgrass prairies of North America were represented by Rhizobium and Methylobacterium species of the $\alpha$-Proteobacteria, Burkholderia and Azoarcus species of the $\beta$-Proteobacteria and Desulfuromonas and Geobacter species of the $\delta$ Proteobacteria [3].

The genus Burkholderia, the members of the $\beta$ Proteobacteria class in the context of results from the current study deserve the most attention. This bacterial group was reported to contain most of all species that nodulate legumes; however, several families are included also in $\alpha$ Proteobacteria, i.e. Methylobacterium [57]. What is more, Burkholderia genus are known to be versatile organisms that occupy a wide range of ecological niches $[24,58]$, i.e. soil (also contaminated), water (also sea water), rhizosphere, humans and hospital environment. This testifies that those bacterial groups are resistant to different stresses and possess quick ability for adaptation in different environments. The current study demonstrated its domination in agricultural soils rather than in wastelands. The genus Burkholderia comprises over 60 species; majority of which, were verified as an effective nitrogen fixers [22, 58], with B. cepacia at the forefront [59].

Unfortunately, data above presented advantages that some Burkholderia species have been involved in human and plants infections and classified as pathogens [24]. Fortunately, the majority of Burkholderia species are known as soil bacteria, exhibited rather non-pathogenic interactions with plants, i.e. they promote plant growth, can degrade the organic compounds of anthropogenic origin and/or may result in biocontrol of pathogens $[24,58,59]$. Burkholderia species also have the potential to be used as plant-growth-promoting rhizobacteria as some mechanisms to promote plant growth in this genus were detected [59]. This fact is important for a potential use of Burkholderia in agriculture. The first known diazotroph was Burkholderia vietnamiensis isolated from the rhizosphere of young rice seedlings in Vietnam [60]. It was also reported that soil inoculation with Burkholderia brasiliense and B. vietnamiensis resulted in 42-64\% increase in growth of rice plants [61]. Moreover, endophytes of Burkholderia occurring in the Brazilian rice roots, steam and leafs are able to fix $31 \%$ of $\mathrm{N}$ that protect the rice plantation and stimulate even by $69 \%$ rice crop when compared with the control condition [61].

In relation to Devosia, the significant decrease of OTU number in comparison with other microbiota was observed. The genus Devosia was created from the reclassification of Pseudomonas riboflavia as Devosia riboflavia [62] and comprised eight well-recognised species [63]. Among these, only D. neptuniae was isolated from an aquatic leguminous plant and reported to possess the nitrogen-fixing (nifH) and the nodulating (nodD) symbiotic genes [64, 65].

We also found in Polish arable soils a high relative abundance of $16 \mathrm{~S}$ rRNA sequences assigned to free-living Cyanobacteria, which suggest that their activity may be of ecological importance at the study site. Vijayan and Ray [66] indicated that there are positive correlations on the total number of Cyanobacteria inhabiting tropical paddy wetland to total nitrogen in these soils. Wakelin et al. [1] assumed that $\mathrm{N}_{2}$ fixed by those bacterial group is important in providing $\mathrm{N}$ pool necessary to support the decomposition of crop residues usually characterised by a wide $\mathrm{C} / \mathrm{N}$ ratio. Chouhan and Kumawat [67] isolated six strains of Cyanobacteria from agricultural and grassland soils, which were assigned to the following genera: Oscillatoria, Fischerella, Nostoc, Synechocystis and Gloeocapsa. The obtained results indicated that Cyanobacteria belonging to the genera Fischerella and Nostoc can be used in biofertiliser production to improve agriculture and grassland soil fertility. What is more, they also provide nitrogen to plants and other organisms and are able to survive in both wet and dry conditions [67].

Our results also indicate that PNF bacteria may be sensitive on agricultural practices as well as could show resistance in response to agricultural way of land use and consequently remain insensitive. The PNF bacteria that potentially inhabit the LG and HG soils seemed to be definitely sensitive on agricultural operations as decrease of its OTU number in A soils was observed (Table 7). However, we demonstrated that microorganisms belonging to $\beta$-Proteobacteria in all studied soils displayed resistance to agricultural way of land use; therefore, there are the dominant group of PNF microorganisms in tested soils (Table 6). What is more, the abundance of $\beta$-Proteobacteria is higher in agricultural than control soils. Our results also demonstrated that agricultural operations had 
Table 6 Well recognised nitrogen-fixing bacterial communities in different region in the world

\begin{tabular}{|c|c|c|c|c|}
\hline Study regions & Average soil $\mathrm{pH}$ & Dominant phyla & Predominant genera & Reference \\
\hline Antarctica-wetted soil & 8.48 & $\begin{array}{l}\alpha \text {-Proteobacteria } \\
\beta \text {-Proteobacteria } \\
\gamma \text {-Proteobacteria } \\
\delta \text {-Proteobacteria } \\
\text { Cyanobacteria }\end{array}$ & Geobacter & {$[53]$} \\
\hline Antarctica microbial mat & 9.90 & $\begin{array}{l}\beta \text {-Proteobacteria } \\
\gamma \text {-Proteobacteria } \\
\delta \text {-Proteobacteria } \\
\text { Firmicutes } \\
\text { Spirochaetes } \\
\text { Cyanobacteria } \\
\text { Verrucomicrobia } \\
\text { Unidentified cluster }\end{array}$ & Azotobacter & {$[68]$} \\
\hline Canadian Arctic scrubland soil & - & $\begin{array}{l}\alpha \text {-Proteobacteria } \\
\beta \text {-Proteobacteria } \\
\gamma \text {-Proteobacteria } \\
\text { Firmicutes } \\
\text { Unidentified cluster }\end{array}$ & Rhodopseudomonas & {$[54]$} \\
\hline Arctic tundra soil & 6.70 & $\begin{array}{l}\alpha \text {-Proteobacteria } \\
\gamma \text {-Proteobacteria } \\
\delta \text {-Proteobacteria } \\
\text { Spirochaetes } \\
\text { Cyanobacteria } \\
\text { Spirochaetes } \\
\text { Unidentified cluster }\end{array}$ & Rhodopseudomonas & {$[55]$} \\
\hline Tibetan plateau alpine prairie soil & 7.43 & $\begin{array}{l}\alpha \text {-Proteobacteria } \\
\beta \text {-Proteobacteria } \\
\gamma \text {-Proteobacteria } \\
\delta \text {-Proteobacteria } \\
\text { Unidentified cluster }\end{array}$ & Methylocella & {$[56]$} \\
\hline Qilian mountains scrubland and meadow soil & 7.04 & $\begin{array}{l}\alpha \text {-Proteobacteria } \\
\beta \text {-Proteobacteria } \\
\gamma \text {-Proteobacteria } \\
\text { Unidentified cluster }\end{array}$ & Bradyrhizobium & {$[25]$} \\
\hline Polish agriculture soils & 5.51 & $\begin{array}{l}\alpha \text {-Proteobacteria } \\
\beta \text {-Proteobacteria }\end{array}$ & Burkholderia & This study \\
\hline Polish wastelands soils & 6.15 & $\begin{array}{l}\alpha \text {-Proteobacteria } \\
\beta \text {-Proteobacteria }\end{array}$ & Burkholderia & \\
\hline
\end{tabular}

positive impact on the Cyanobacteria populations as we observed increasing trend in OTU number classified to Cyanobacteria in A soils, especially from $\mathrm{HG}$ group (Table 7).

In summary, these results demonstrated that Polish arable soils are decidedly dominated by PNF bacteria from the $\beta$ Proteobacteria class and Burkholderia genus. Subdominants are bacteria of $\alpha$-Proteobacteria class and Devosia genus. Cyanobacteria population dominated in agricultural rather than in control soils. PNF bacteria classified as rare OTUs were represented by the genera of Rhizobium, Microvirga,
Table 7 The number of PNF bacteria OTUs in the three groups of control (C) and agricultural (A) soils

\begin{tabular}{|c|c|c|c|c|c|c|}
\hline & \multicolumn{2}{|c|}{ Lithogenic soils } & \multicolumn{2}{|c|}{ Autogenic soils } & \multicolumn{2}{|c|}{ Hydrogenic soils } \\
\hline & $\mathrm{C}$ & A & $\mathrm{C}$ & A & $\mathrm{C}$ & $\mathrm{A}$ \\
\hline Proteobacteria & 13 & 9 & 87 & 99 & 55 & 63 \\
\hline$\alpha$-Proteobacteria & 8 & 5 & 31 & 34 & 22 & 16 \\
\hline$\beta$-Proteobacteria & 5 & 4 & 56 & 65 & 33 & 47 \\
\hline Cyanobacteria & 1 & 2 & 15 & 17 & 2 & 14 \\
\hline
\end{tabular}


Methylobacterium and Phyllobacterium. Their abundance was directly connected with the soil formation process as most of them inhabit the autogenic group of soils formed on the loess material whilst the lowest PNF bacteria number was noted in the lithogenic soils, formed on limestone. What is more, in the lithogenic soil biodiversity of PNF bacteria was menacingly limited as lack of Cupriavidus, Methylobacterium and Phyllobacterium genera was stated. We also demonstrated that lithogenic soils demand additional fertiliser application as they seemed to be the most requiring and sensitive on $\mathrm{N}$ pool in the ground, in contrary to autogenic and hydrogenic soils. Determined optimal niche conditions preferable by PNF bacteria are as follows: neutral or alkaline $\mathrm{pH}, \mathrm{EC}$ on the level at least $0.05-0.08 \mathrm{mS} \mathrm{cm}^{-3}$, and $\mathrm{EDC}>1300 \mathrm{mg} \mathrm{kg}^{-1}$; otherwise, it is a limiting factor for PNF growth. Effect posed by $\mathrm{NO}_{3}-\mathrm{N}$ remain unrecognisable and demand more studies as we observed its positive effect with regard to Microvirga, Cyanobacteria in LG soils, Cupriavidus in AG and HG soils, neutral with respect to Burkholderia, Mesorhizobium, Devosia and Methylobacterium in AG soils, and negative in relation to Rhizobium in AG and HG soils, Methylobacterium in HG soils and Cupriavidus in HG soils.

Acknowledgments This project was partly funded by the National Science Centre (Poland), grant no. DEC-2013/09/D/NZ9/02482. The authors are grateful to Marek Pazur from the Institute of Agrophysics Polish Academy of Sciences in Lublin (Poland) for his participation in the field trip and help in precise location of BSS sampling sites.

Open Access This article is distributed under the terms of the Creative Commons Attribution 4.0 International License (http:// creativecommons.org/licenses/by/4.0/), which permits unrestricted use, distribution, and reproduction in any medium, provided you give appropriate credit to the original author(s) and the source, provide a link to the Creative Commons license, and indicate if changes were made.

\section{References}

1. Wakelin SA, Gupta VVSR, Forrester ST (2010) Regional and local factors affecting diversity, abundance and activity of free-living, $\mathrm{N}_{2}$-fixing bacteria in Australian agricultural soils. Pedobiologia 53:391-399

2. Simon Z, Mtei K, Gessesse A, Ndakidemi PA (2014) Isolation and characterization of nitrogen fixing rhizobia from cultivated and uncultivated soils of northern Tanzania. Am J Plant Sci 5:4050-4067

3. Bahulikar RA, Torres-Jerez I, Worley E, Craven K, Udvardi MK (2014) Diversity of nitrogen-fixing bacteria associated with switchgrass in the native tallgrass praire of northern Oklahoma. Appl Environ Microbiol 80(18):5636-5643

4. Cobo-Diaz JF, Fernandez-Gonzalez AJ, Villadas PJ, Robles AB, Toro N, Fernandez-Lopez M (2015) Metagenomic assessment of the potential microbial nitrogen pathways in the rhizosphere of a Mediterranean forest after a wildfire. Microb Ecol 69:895-904

5. Saadatnia H, Riahi H (2009) Cyanobacteria from paddy fields in Iran as biofertilizer. Plant Soil 55:207-212
6. Mishra U, Pabbi S (2004) Cyanobacteria: a potential biofertilizer for rice. Resonance 9:6-10

7. Garcia-Pichel F, Pringault O (2001) Microbiology: Cyanobacteria track water in desert soil. Nature 413:380-381

8. Begum ZNT, Mandal R, Amin FB (2013) Growth of Cyanobacteria in saline soil amended with NP fertilizer. J Asiat Soc Bangladesh 39(2):167-171

9. Karnieli A, Kidron GJ, Glaesser C, Ben-Dor E (1999) Spectral characteristics of Cyanobacteria soil crust in semiarid environments. Remote Sens Environ 69:67-75

10. Jaramillo PMD, Guimaraes AA, Florentino LA, Silva K, Simao R, Nobrega A, de Souza Moreira FM (2013) Symbiotic nitrogenfixing bacterial populations trapped from soils under agroforestry systems in the Western Amazon. Sci Agric 70(6):397-404

11. Falkowski PG (1997) Evolution of the nitrogen cycle and its influence on the biological sequestration of $\mathrm{CO}_{2}$ in the ocean. Nature 387:272-275

12. Xu CW, Yang MZ, Chen YJ, Chen LM, Zhang DZ, Mei L, Shi YT, Zhang HB (2012) Changes in noon-symbiotic nitrogen-fixing bacteria inhabiting rhizosphere soil of an invasive plant Ageratina adenophora. Appl Soil Ecol 54:32-38

13. Cleveland CC, Townsend AR, Schimel DS, Fisher H, Howarth RW, Hedin LO et al (1999) Global patterns of terrestrial biological nitrogen $\left(\mathrm{N}_{2}\right)$ fixation in natural ecosystems. Global Biogeochem Cycles 13(2):623-645

14. Fotyma EF, Fotyma M, Pietruch CZ (2004) The content of mineral nitrogen $\mathrm{N}$ min in arable soils of Poland. Nawozy i Nawożenie 3(20):11-53 (in Polish)

15. Bednarek W, Reszka R (2008) Influence of liming and mineral fertilization on the content of mineral nitrogen in soil. J Elementol 13(3):301-308

16. Dresler S, Bednarek W, Tkaczyk P (2011) Nitrate nitrogen in the soils of eastern Poland as influenced by type of crop, nitrogen fertilization and various organic fertilizers. J Cent Eur Agric 12(2):367-379

17. Polish Statistical Office (2014) Agriculture in Lublin province. ISSN 2080-0517, Lublin, pp. 41-43 (in Polish)

18. Mohammadi K, Sohrabi Y (2012) Bacterial biofertilizers for sustainable crop production: a review. J Agric Biol Sci 7:307-316

19. Cummings SP, Humphry DR, Santos SR, Andrews M, James EK (2006) The potential and pitfalls of exploiting nitrogen fixing bacteria in agricultural soils as a substitute for inorganic fertiliser. Environ Biotechnol 2(1):1-10

20. Willems A (2006) The taxonomy of rhizobia: an overview. Plant Soil 287:3-14

21. Trujillo ME, Willems A, Abril A, Planchuelo AM, Rivas R, Ludena D, Mateos PF, Martinez-Molina E, Velazquez E (2005) Nodulation of Lupinus albus by strain of Ochrobactrum lupinae sp. nov. Appl Environ Microbiol 71(3):1318-1327

22. Govindarajan M, Balandreau J, Kwon SW, Weon HY, Lakshminarasimhan C (2008) Effects of the inoculation of Burkholderia vietnamensis and related endophytic diazotrophic bacteria on grain yield of rice. Microb Ecol 55:21-37

23. Valverde A, Velazquez E, Gutierrez C, Ventosa A, Iqual JM (2003) Herbaspirillum lusitanum sp. nov., a novel nitrogen-fixing bacterium associated with root nodules of Phaseolus vulgaris. Int J Syst Evol Microbiol 53(6):1979-1983

24. Coyenye T, Vandamme P (2003) Diversity and significance of Burkholderia species occupying diverse ecological niches. Environ Microbiol 5(9):719-729

25. Tai XS, Mao WL, Liu GX, Chen T, Zhang W, Wu XK, Long HZ, Zhang BG, Zhang Y (2013) High diversity of nitrogen-fixing bacteria in the upper reaches of the Heihe River, northwestern China. Biogeosciences 10:5589-5600 
26. Matiru VN, Dakora FD (2004) Potential use of rhizobial bacteria as promoters of plant growth for increased yield in Landraces of African cereal crops. Afr J Biotechnol 3:1-7

27. Soni R, Suyal DC, Sai S, Goel R (2016) Exploration of nifH gene through soil metagenomes of the western Indian Himalayas. 3 Biotech 6:25. doi:10.1007/s13205-015-0324-3

28. Lüke C, Speth DR, Kox MAR, Villanueva L, Jetten MSM (2016) Metagenomic analysis of nitrogen and methane cycling in the Arabian sea oxygen minimum zone. PeerJ 4:e1924. doi:10.7717/peerj.1924

29. Dai Z, Guo X, Yin H, Liang Y, Cong J, Liu X (2014) Identification of nitrogen-fixing genes and gene clusters from metagenomic library of acid mine drainage. PLoS One 9(1):e87976. doi:10.1371 /journal.pone.0087976

30. Souza RC, Cantão ME, Ribeiro-Vasconcelos AT, Nogueira MA, Hungria M (2013) Soil metagenomics reveals differences under conventional and no-tillage with crop rotation or succession. Appl Soil Ecol 72:49-61

31. Bieganowski A, Witkowska-Walczak B, Gliński J, Sokołowska Z, Sławiński C, Brzezińska M, Włodarczyk T (2013) Database of Polish arable mineral soils: a review. Int Agrophys 27:335-350

32. Gliński J, Ostrowski J, Stępniewska Z, Stępniewski W (1991) Soil samples bank representing mineral soils of Poland. Probl Agrophys 66:5-57 (in Polish)

33. PN-R-04031:1997. Chemical and agricultural soil analyses. Soil sampling. PKN (in Polish)

34. Lamorski K, Bieganowski A, Ryżak M, Sochan A, Sławiński C, Stelmach W (2014) Assessment of the usefulness of particle size distribution measured by laser diffraction for soil water retention modelling. J Plant Nutr Soil Sci 117:803-813

35. Wolińska A, Szafranek-Nakonieczna A, Zielenkiewicz U, Tomczyk-Żak K, Banach A, Błaszczyk M, Stepniewska Z (2016) Quantified characterization of soil biological activity under crop cultivation. J Adv Biol 8(3):1655-1665

36. Weil RR, Islam KR, Stine MA, Gruver JB, Samson-Liebig SE (2003) Estimating active carbon for soil quality assessment: a simplified method for laboratory and field use. Am J Altern Agric 18:3-17

37. Wolińska A, Szafranek-Nakonieczna A, Banach A, Rekosz-Burlaga H, Goryluk-Salmonowicz A, Błaszczyk M, Steppniewska Z, Górski A (2014) Biological degradation of agricultural soils from Lublin region (SE Poland). Int J Curr Microbiol Appl Sci 3(11):558-571

38. Wolińska A, Rekosz-Burlaga H, Goryluk-Salmonowicz A, Błaszczyk M, Stępniewska Z (2015) Bacterial abundance and dehydrogenase activity in selected agricultural soils from Lublin region. Pol J Environ Stud 24(6):2677-2682

39. Wolińska A, Szafranek-Nakonieczna A, Banach A, Błaszczyk M, Stępniewska Z (2016) The impact of agricultural soil usage on activity and abundance of ammonifying bacteria in selected soils from Poland. Springer Plus 5:565. doi:10.1186/s40064-016-2264-8

40. Tomczyk-Żak K, Kaczanowski S, Drewniak Ł, Dmoch Ł, Skłodowska A, Zielenkiewicz U (2013) Bacteria diversity and arsenic mobilization in rock biofilm from an ancient gold and arsenic mine. Sci Total Environ 461:330-340

41. Schloss PD, Westcott SL, Ryabin T, Hall JR, Hartmann M, Hollister EB et al (2009) Introducing MOTHUR: open-source, platform-independent, community-supported software for describing and comparing microbial communities. Appl Environ Microbiol 75:7537-7541

42. Quast C, Pruesse E, Yilmaz P, Gerken J, Schweer T, Yarza P, Peplies J, Glöckner FO (2013) The SILVA ribosomal RNA gene database project: improved data processing and Web-based tools. Nucleic Acids Res 41:590-596

43. Edgar RC, Haas BJ, Clemente JC, Quince C, Knight R (2011) UCHIME improves sensitivity and speed of chimera detection. Bioinformatics 27(16):2194-2200

44. Ondov BD, Bergman NH, Philippy AM (2011) Interactive metagenomic visualization in a Web browser. BMC Bioinf 12: 385. doi:10.1186/1471-2105-12-385
45. Ondrišík P, Porhajašová J, Urminská J, Ňaršanská M (2009) The effect of agrotechnical interventions on seasonal changes of inorganic nitrogen content in soil. J Cent Eur Agric 10:101-108

46. Wood SA, Bradford MA, Gilbert JA, McGuire KL, Palm CA, Tully KL, Zhou J, Naeem S (2015) Agricultural intensification and the functional capacity of soil microbes on small holder African farms. Appl Ecol 52(3):744-752

47. Montecchia MS, Tosi M, Soria MA, Vogrig JA, Sydorenko O, Correa OS (2015) Pyrosequencing reveals changes in soil bacterial communities after conversion of Yungas forests to agriculture. PLoS One. doi:10.1371/journal.pone.0119426

48. Bartram AK, Jiang X, Lynch MDJ, Masella AP, Nicol GW, Dushoff J, Neufeld JD (2014) Exploring links between $\mathrm{pH}$ and bacterial community composition in soils from Craibstone experimental farm. FEMS Microbiol Ecol 87:403-415

49. Zhan J, Sun Q (2011) Diversity of free-living nitrogen-fixing microorganisms in wastelands of copper mine tailings during the process of natural ecological restoration. J Environ Sci 23:476-487

50. Hayden HL, Drake J, Imfof M, Oxley APA, Norng S, Mele PM (2010) The abundance of nitrogen cycle genes amoA and nif $\mathrm{H}$ depends on land-uses and soil types in South-Eastern Australia. Soil Biol Biochem 42:1774-1783

51. Romero IC, Jacobson M, Fuhrman JA, Fogel M, Capone DG (2012) Long-term nitrogen and phosphorus fertilization effects on $\mathrm{N} 2$ fixation rates and nif $H$ gene community patterns in mangrove sediments. Mar Ecol 33:117-127

52. Degefu T, Wolde-Meskel W, Liu B, Cleenwerck I, Willems A, Frostegard A (2013) Mesorhizobium shonense sp. nov., Mesorhizobium hawassense sp. nov. and Mesorhizobium abyssinicae sp. nov., isolated from root nodules of different agroforestry legume trees. Int J Syst Evol Microbiol 63:1746-1753

53. Niederberger TD, Sohm JA, Tirindelli J, Gunderson T, Capone DG, Carpenter EJ, Cary SC (2012) Diverse and highly active diazotrophic assemblages inhabit ephemerally wetted soils of the Antarctic Dry Valleys. FEMS Microbiol Ecol 82:376-390. doi:10.1111/j.1574-6941.2012.01390.x

54. Deslippe J, Egger K (2001) Molecular diversity of nifH genes from bacteria associated with high Arctic Dwarf Shrubs. Microb Ecol 51: 516-525. doi:10.1007/s00248-006-9070-8

55. Izquierdo J, Nüsslein K (2006) Distribution of extensive nifH Gene diversity across physical soil microenvironments. Microb Ecol 51: 441-452. doi:10.1007/s00248-006-9044-X

56. Zhang Y, Li D, Wang H, Xiao Q, Liu X (2006) Molecular diversity of nitrogen-fixing bacteria from the Tibetan Plateau, China. FEMS Microbiol Lett 260:134-142. doi:10.1111/j.15746968.2006.00317.x

57. Sy A, Giraud P, Jourand N, Garcia A, Willems A, de Lajudie P, Prin Y, Neyra M, Gillis M (2001) Methylotrophic Methylobacterium bacteria nodulate and fix nitrogen in symbiosis with legumes. J Bacteriol 183:214-220

58. Suarez-Moreno Z, Caballero-Mellado J, Coutinho BG, MendoncaPreviato L, James EK, Venturi V (2012) Common features of environmental and potentially beneficial plant-associated Burkholderia. Microb Ecol 63:249-266

59. da Silva K, de Souza CA, Silva Lima A, De Brandt E, Pinnock E, Vandamme P, de Souza Moreira FM (2012) Diazotrophic Burkholderia species isolated from the Amazon region exhibit phenotypical, functional and genetic diversity. Syst Appl Microbiol 35:253-262

60. Gillis M, Van Van T, Bardin R, Goor M, Hebbar P, Willems A et al (1995) Polyphasic taxonomy in the genus Burkholderia leading to an emended description of the genus and proposition of Burkholderia vietnamiensis $\mathrm{sp}$. nov. for $\mathrm{N}_{2}$-fixing isolates from rice in Vietnam. Int J Syst Bacteriol 45:274-289

61. Baldani VLD, Baldani JI, Dobereiner J (2000) Inoculation of rice plants with the endophytic diazotrophs Herbaspirillum seropedicae and Burkholderia spp. Biol Fertil Soils 30:485-491 
62. Nakagawa Y, Sakane T, Yokota A (1996) Transfer of "Pseudomonas riboflavina" (Foster 1944), a Gram-negative, motile rod with long-chain 3-hydroxy fatty acids, to Devosia riboflavina gen. nov., nom. rev. Int J Syst Bacteriol 46:16-22

63. Bautista VV, Monsalud RG, Yokota A (2010) Devosia yakushimensis sp. nov., isolated from root nodules of Pueraria lobata (Willd.) Ohwi. Int J Syst Evol Microbiol 60:627-632

64. Rivas R, Velazquez E, Willems A, Vizcanino N, Subba-Rao NS, Mateos PF, Gillis M, Dazzo FB, Martinez-Molina E (2002) A new species of Devosia that forms a unique nitrogen-fixing root-nodule symbiosis with the aquatic legume Neptunia natans (L.f.) Druce. Appl Environ Microbiol 68:5217-5222

65. Rivas R, Willems A, Subba-Rao NS, Vizcanino N, Mateos PF, Dazzo FB, Kroppenstedt RM, Martinez-Molina E, Gillis M,
Velazquez E (2003) Description of Devosia neptuniae sp. nov. that nodulates and fixes nitrogen in symbiosis with Neptunia natans, an aquatic legume from India. Syst Appl Microbiol 26:47-53

66. Vijayan D, Ray JG (2015) Ecology and diversity of Cyanobacteria in Kuttanadu paddy wetlands, Kerala, India. Am J Plant Sci 6: 2924-2938

67. Chouhan PK, Kumawat DK (2014) Screening of Cyanobacteria from Black Cotton soil and evaluate their potential to survive under wet and dry condition for biofertilizer production. Sch J Agric Vet Sci 1(2):90-99

68. Jungblut AD, Neilan BA (2010) NifH gene diversity and expression in a microbial mat community on the McMurdo Ice Shelf Antarctica. Antarct Sci 22:117-122. doi:10.1017/S0954102009990514 